\title{
Advances in microbial bioremediation and the factors influencing the process
}

\author{
J. Srivastava $\cdot$ R. Naraian $\cdot$ S. J. S. Kalra • \\ H. Chandra
}

Received: 17 June 2013/Revised: 25 July 2013/Accepted: 2 November 2013/Published online: 27 November 2013

(C) Islamic Azad University (IAU) 2013

\begin{abstract}
Irrational and rapid global human societal development has culminated to a condition of environmental deterioration. Accidental leakage and deliberate use of organic and inorganic chemicals have contaminated the environment up to the level of ecosystem. Advancements have been made in the field of research on bioremediation of the hazardous contaminants especially in last three decades. Microbial bioremediation has been the most understood biotechnological process of environmental restoration. Bacteria and fungi because of their inherent ability to adapt and grow in extreme environments have been employed for either removal or degradation of the chemical contaminants. Researchers all over the world are getting breakthroughs in finding new bacterial strains having plasmid linked degradation/ reduction ability. Molecular biology and genetic engineering helped in crafting the microbes for the desired results on environment. Despite having favorable conditions, microbial remediation largely depends on
\end{abstract}

J. Srivastava $(\square)$

Department of Applied Science, Faculty of Environmental

Science, Himalayan Institute of Technology and Management, BKT, NH - 24, Lucknow 227005, UP, India

e-mail: jks_345@rediffmail.com

R. Naraian

Department of Biotechnology, Faculty of Science, Veer Bahadur Singh Purvanchal University, Jaunpur, UP, India

S. J. S. Kalra

Department of Chemistry, Dayanand Anglo Vedic College, Civil Lines, Kanpur, UP, India

H. Chandra

Department of Medicinal and Aromatic Plants, High Altitude Plant Physiology Research Center, H.N.B. Garhwal University, Srinagar, Uttrakhand, India environmental factors and on the basic biological characters of microbes, especially bacteria being Grampositive or Gram-negative. Metagenomic studies revealed the importance of microbial ecology as microbes work well in community, i.e., consortia. This review along with several other studies suggests the need of precision during microbial community identification, substrate specificity and the designing of microbes.

Keywords Environmental contamination - Climate change - Bioremediation · Plasmids - Metagenomics . Gram-positive bacteria $\cdot$ Gram-negative bacteria

\section{Introduction}

Environmental degradation signifies the damages of varying degrees to the soil, water and air characterized by substantial physicochemical alterations. Several remedies (natural and man-made) have been suggested in last three decades to mitigate the pollution from the environment. The literature is vast and is far beyond the capacity to be included here, however, e.g., Lovely (2003), Paul et al. (2005), Singh et al. (2006), Wei et al. (2007), Badri et al. (2009), Chojnacka (2010), Magan et al. (2010), Rajkumar et al. (2010), Glick (2010), Maphosa et al. (2012) and Zhang et al. (2012), delineating latest and upgraded techniques involving living organisms, specifically plants and microbes, for the removal and/or immobilization of contaminants, known as bioremediation. Phytoremediation (remediation through plants) is a novel approach (Shukla et al. 2009), however; it has certain technical shortcomings such as management of biomass (Wei et al. 2007) and the growth conditions as plants are restricted only to 
certain geographical regions. As far as the microbial species are concerned, only $5 \%$ microbial diversity is known to date and $95 \%$ is yet to explore. Successful microbial bioremediation is achieved when microbes interact within their niche, under the most favorable conditions (Riccardi et al. 2005). Biostimulation (enhancing the activity of native microbes), bioaugmentation (increasing the viable microbial counts), bioaccumulation (storage of toxic or nontoxic elements by the microbes) (Vasudevan et al. 2001; Tyagi et al. 2011), biosorption (removal of elements from the environment through adsorption) (Gupta et al. 2000) and the use of biofilms (Singh et al. 2006) are some of the examples of recent advancements in microbial bioremediation techniques. Bioremediation involves a number of species of microbes having different mechanisms depending upon the environmental factors and the nature of chemicals (Boopathy 2000) either to degrade or to remove the toxic contaminants from the environment. Elevated ambient atmospheric temperature (a climate change factor) may have impacts on the microbial activity (Margesin and Schinner 2001), especially on the upper layers of soils subjected to the contamination. In addition, such extreme environmental conditions may change microbial count and the diversity as well. In the present review, the current state of knowledge regarding microbial remediation along with the brief review of the factors influencing the processes has been reviewed.

\section{Microbial bioremediation}

Microbial bioremediation is the natural way to mitigate environmental pollution. The process includes the activities of aerobic and anaerobic microorganisms. Despite having different nutritional requirements, both life forms have basic need of organic carbon and a source of energy. There are several regions other than the typical ones, such as soil, water and sediments, which can be identified as the potential site of microbial actions. Such regions include the rhizospheric zone of plants, gravel-associated community, aquatic shorelines, subsurface layer of marshland and the weathered rocks. Higher microbial counts and diversity is directly associated with the higher content of organic matter in soil (Boopathy 2000), however; the presence of organic substances of high molecular weight such as polycyclic aromatic hydrocarbons (PAHs) may limit the microbial activity (Nam et al. 2001). On the contrary, Hesham et al. (2012) reported the degradation of chrysene and benzo(a)pyrene (PAHs of high molecular weight) by the yeast fungi (Table 2) up to 98.5 and $95.2 \%$, respectively, in soil. In addition to this, several recent reports (Zhuang et al. 2012; Torres-Bojorges and Buitron 2012; Chiang et al. 2012; Yassine et al. 2013) suggest that the nature and occurrence of chemicals hardly disturb the bioremediation process. Generally, organisms rely upon associations with their neighbors for the sustenance of life (Badri et al. 2009). Microbes also interact with other organisms within their surroundings for organic carbon, energy and shelter, such as arbuscular mycorrhizal fungi (Harrison 2005) and plant-growthpromoting rhizobia (Bais et al. 2006), protecting the host organisms from several environmental toxic chemicals (Arriagada et al. 2007; Srivastava et al. 2010). Microbes have wider range of growing conditions and can withstand higher concentrations of chemical contaminants. For better understanding, microbial bioremediation can be classified on the basis of the nature of substrate undergoing either removal or degradation into two, viz., (1) microbial remediation of inorganic contaminants and (2) microbial remediation of organic contaminants (OCs).

Microbial remediation of inorganic contaminants

Major inorganic contaminants include toxic heavy metals and their compounds originated from various industrial processes, such as mining, metallurgy, power plants and chemical manufacturing processes (Goyal et al. 2003). In general, toxic elemental pollution is one of the major concerns of environmentalists and biologists because the disposal of toxic metals to the surface, subsurface soils and waters causes unacceptable health risks (Kaewsarn and Yu 2001). Microbiological removal of metal ions from the environment is a new biotechnique (Shukla et al. 2009) and the most cost-effective approach in mitigation of elemental pollution. Heavy metals and their removal are well-researched issues as evident from the existing research literatures (Lovely and Coates 1997; Lovely and Lloyd 2000; Garbisu and Alkorta 2003; Malik 2004; Shukla and Rai 2006; Kabata-Pendias and Mukherjee 2007; Kim et al. 2007; Srivastava et al. 2008; Badri et al. 2009; Rajkumar et al. 2013) and the references therein. It is imperative to know that microbes in any case cannot degrade the metal ions and are only able to transform metallic ions from higher to lower oxidation states to stabilize them (Garbisu and Alkorta 2003). Further microbes are able to metabolize, detoxify and accumulate metals mostly in cell wall like any other nutrient element. Table 1 presents few examples of toxic metal-remediating microbes. Microbes releasing chelating agents and acids altering physicochemical properties such as redox potential (Eh) of surroundings (Abou-Shanab et al. 2003) bring 
Table 1 Microbes (bacteria and fungi) and the remediated elemental pollutants

\begin{tabular}{|c|c|c|c|c|}
\hline Microbial species & Gram \pm & Occurrence & Remediated metal & References \\
\hline Pseudomonas putida & $\operatorname{Gram}(-\mathrm{ve})$ & Soil and sediments & $\mathrm{Cu}$ & Wood and Wang (1985) \\
\hline Ralstonia eutropha & $\operatorname{Gram}(-\mathrm{ve})$ & Soil and sediments & Ni resistant & Mergeay (1991) \\
\hline Acenetobacter sp. & $\operatorname{Gram}(-\mathrm{ve})$ & Sediments & Cyanide salts & Finnegan et al. (1991) \\
\hline Helicobacter pylori & $\operatorname{Gram}(-\mathrm{ve})$ & Soil and sediments & $\mathrm{Ni}$ & Hendricks and Mobley (1997) \\
\hline Pseudomonas stutzeri & $\operatorname{Gram}(-\mathrm{ve})$ & Soil and sediments & $\mathrm{Ni}$ & Joerger et al. (2001) \\
\hline Staphylococcus carnosus & Gram (+ve) & Soil and sediments & $\mathrm{Cd}$ and $\mathrm{Ni}$ & Samuelson et al. (2000) \\
\hline Pseudomonas spp. & $\operatorname{Gram}(-\mathrm{ve})$ & Soil and sediments & $\mathrm{U}$ accumulator & Sar and D’Souza (2001) \\
\hline Aspergillus niger & Fungi & Soil and sediments & $\mathrm{Cr}(\mathrm{VI})$ & Goyal et al. (2003) \\
\hline Saccharomyces cerevisiae & Fungi & Sediments & $\mathrm{Cr}(\mathrm{VI})$ & Goyal et al. (2003) \\
\hline Gallionella ferruginea, & Gram (-ve) & Sediments & As (adsorption) & Katsoyiannis and Zouboulis (2004) \\
\hline Leptothrix ochracea & $\operatorname{Gram}(-\mathrm{ve})$ & & & \\
\hline Lentinus sajor-caju & Fungi & Sediments & $\mathrm{U}$ & Bayramoğlu et al. (2006) \\
\hline Salmonella spp. & $\operatorname{Gram}(-\mathrm{ve})$ & Sediments & $\mathrm{Zn}(\mathrm{II})$ & Nweke et al. (2007) \\
\hline Desulfovibrio spp., Geobacter spp, & $\begin{array}{l}\text { Gram }(-v e) \\
\text { Gram }(-v e)\end{array}$ & Soil & $\mathrm{U}(\mathrm{VI})$ & Cardenas et al. (2008) \\
\hline Acidovorax spp. & $\operatorname{Gram}(-\mathrm{ve})$ & Soil & $\mathrm{U}(\mathrm{VI})$ & Cardenas et al. (2008) \\
\hline Pseudomonas spp. & Gram $(+v e)$ & Wastewater & $\mathrm{Cr}(\mathrm{VI})$ & Srivastava et al. (2008) \\
\hline Aspergillus flavus & Fungi & Soil & $\mathrm{Cr}(\mathrm{III})$ & Han and Gu (2010) \\
\hline Cenarchaeum spp. & Gram $(-v e)$ & Sediment and soil & $\mathrm{NH}_{4}^{+}$oxidizing & Hong et al. (2012) \\
\hline Trichoderma asperellum & Fungi & Sediment & $\mathrm{Cu}$ (II) & Tan and Ting (2012) \\
\hline Geobacter bemidjiensis & Gram (-ve) & Sediment & $\mathrm{Fe}(\mathrm{III})$ & Luef et al. (2013) \\
\hline Desulfovibrio vulgaris (ATCC 29579) & $\operatorname{Gram}(-\mathrm{ve})$ & Waste water & $\mathrm{Cr}(\mathrm{VI})$ reduction & Mabbett et al. (2002) \\
\hline
\end{tabular}

substantial changes by increasing the bioavailability of metal ions (Abou-Shanab et al. 2006). In addition, physicochemical reaction such as biosorption is the first step in the interaction between microbial cell and metal ions (Han and $\mathrm{Gu}$ 2010) followed by the physical adsorption, ion exchange and complexation (Fig. 1). Biochemical reactions during microbial transformation of metal ions involve the action of specific enzymes for oxidation, reduction, methylation, dealkylation and precipitation (Han and Gu 2010). Microbes have diversified conditions for their growth with ability to adapt to the changing environmental conditions, e.g., Naraian et al. (2012) reported that the multiple-drug-resistant strain of Pseudomonas aeruginosa T-3 isolated from tannery effluent had plasmid-encoded chromate ion resistance, exhibiting the adaptability feature of microbes. Plasmidencoded copper and cadmium metal resistance has also been reported in Pseudomonas putida PhCN (El-Deeb 2009). Advancements in microbial remediation techniques and studies on plasmid-encoded biochemical information and genetic engineering helped in designing new strains of known bacterial species for targeted bioremediation, e.g., recombinant Escherichia coli expressing metallothionein gene (Neurospora crasa) for
Cd uptake, which was more rapid than the gene donor microbial species (Pazirandeh et al. 1995). Staphylococcus xylosus and Staphylococcus carnosus were designed by the introduction of polyhistidyl peptides encoding genes conferring Ni-binding capacity to these microbes (Samuelson et al. 2000).

Microbial remediation of organic contaminants (OCs)

Widespread and massive applications of organic compounds such as biocides, flame retardants, polymers, solvents, crude oil, explosives and chlorinated organic compounds have contaminated the environment, causing threats to most of the life forms on earth. Microbes have proven ability to degrade most of the OCs such as PCBs, PAHs and polybrominated biphenyl ethers (PBEs) in the environment (Hiraishi 2008; Fennell et al. 2011). Bioremediation of OCs in environment is the most studied field of microbiology. Biodegradation of OCs refers to the catabolic activity of microbes transforming them into less or completely nontoxic residues (Margesin et al. 2000). The organic substrate is used by the microbes as the source of organic carbon and energy. Some of the important findings on bioremediation of hazardous 


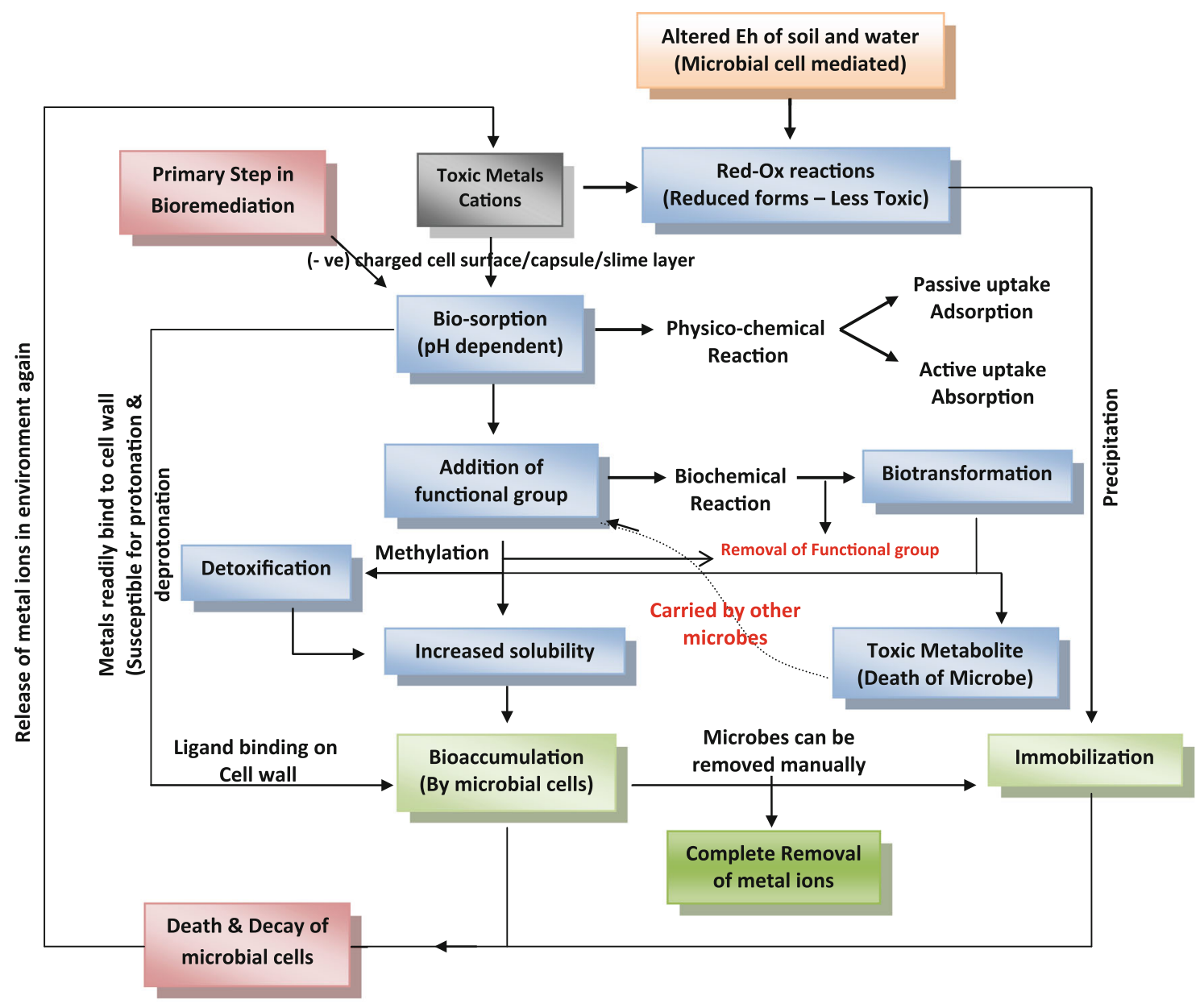

Fig. 1 Most preferable bioremediation mechanisms followed during the interaction between microbes and metal

organics and their mechanisms have been well reported by Watanabe et al. (2000); Widada et al. (2002); Li et al. (2004); Fragoeiro and Magan (2008); Magan et al. (2010); Fennell et al. (2011); Torres-Bojorges and Buitron (2012); Maphosa et al. (2012) and Weber and Leqqe (2013). Table 2 presents a brief index of some microbial species and their strains capable of degrading OCs. In general, single microbial species hardly degrades any organic substrate in isolation (Pieper and Reineke 2000) and works well in community. Interactions between microbes in the community ensure the exchange of genetic information between microbial species conferring resistance, tolerance and chemical-degrading ability. Most often the microbial species that are able to degrade OCs are misidentified owing to the lack of standard microbial identification techniques and laboratory practices in most of the parts of the world (Endy 2005), signifying the importance of researches on the microbial consortia via the tools of metagenomics and the standard genetic engineering protocols. In general, microbes can degrade a variety of organic substances depending upon the plasmid-encoded catabolic processes (Table 3) and chromosomal genes (in case of bacteria) or the extracellular enzymatic activity (fungal degradation process). These processes are further subjected to the varying environmental conditions influencing the growth pattern of microbes (Watanabe 2001) (Fig. 2). In scientific perspective, genetic engineering is one of the elite biotechnological branches offering infinite combinations of genetic codes imparting the knowledge of designing of potentially degrading and substrate-specific microbes (Chaloupkova et al. 2003; Li et al. 2004; Ang et al. 2005; Wood 2008). For a successful bioengineered microbe, it is mandatory to identify the relevant species and their substrate-specific strains (Wood 2008). In addition, genetic modification with DNA reshuffling has provided enormous combinations enabling microbial cells to degrade even the most recalcitrant organic compounds. Apart from recombinant, microbes naturally degrade the recalcitrant OCs by triggering cometabolic 
Table 2 Potentially hazardous organic chemicals and their degrading microbes (bacteria and fungi)

\begin{tabular}{|c|c|c|c|c|}
\hline Microbial species & Gram \pm ve & Occurrence & Organic substrate & References \\
\hline Pseudomonas putida (G7) & $\operatorname{Gram}(-\mathrm{ve})$ & Soil & Naphthalene (PAH) & Grimm and Harwood (1997) \\
\hline Pseudomonas putida (GJ31) & $\operatorname{Gram}(-\mathrm{ve})$ & Soil & Chlorobenzenes & Mars et al. (1997) \\
\hline Klebsiella pneumonia (RS-13) & $\operatorname{Gram}(+\mathrm{ve})$ & Water & $\mathrm{N}, \mathrm{N}$-dimethyl-p- & Wong and Yuen (1998) \\
\hline Acetobacter liquifaciens (S-1) & $\operatorname{Gram}(-\mathrm{ve})$ & & phenylenediamine & \\
\hline Pseudomonas stutzeri & $\operatorname{Gram}(-\mathrm{ve})$ & Soil & Naphthalene & Bosch et al. (2000) \\
\hline Burkholderia spp. & $\operatorname{Gram}(-\mathrm{ve})$ & Soil & $\begin{array}{l}\text { Polycyclic aromatic } \\
\text { hydrocarbons }\end{array}$ & Grosser et al. (2000) \\
\hline Kluyveromyces marxianus (IMB3) & $\begin{array}{l}\text { Yeast } \\
\text { (fungi) }\end{array}$ & Waste water & Remazol Black B & Meehan et al. (2000) \\
\hline Agrobacterium radiobacter $(\mathrm{S} 2)$ & $\operatorname{Gram}(-\mathrm{ve})$ & Waste water & $\begin{array}{l}\text { Sulfonate benzene or } \\
\text { Naphthalene }\end{array}$ & Contzen and Stolz (2000) \\
\hline Phanerochaete chrysosporium & Fungi & Soil & 4,4 dibromodiphenyl ether & Mikulasova et al. (2001) \\
\hline $\begin{array}{l}\text { Vibrio cyclotrophicus sp. nov. (ATCC } \\
700982 \text { ) }\end{array}$ & Gram $(-v e)$ & Soil & Polyaromatic hydrocarbons & Hadlund and Staley (2001) \\
\hline Pseudomonas putida $(\mathrm{F} 1)$ & Gram $(-v e)$ & Soil & Toluene and its derivatives & Leahy et al. (2003), \\
\hline Ralstonia picketti (POK 01) & $\operatorname{Gram}(-\mathrm{ve})$ & & & Parales et al. (2000) \\
\hline Burkholderia cepacia $(\mathrm{G} 4)$ & Gram $(-v e)$ & & & \\
\hline Gliocladium virens & Fungi & Waste water & Lignocellulosic compounds & Murugesan, 2003 \\
\hline Myceliophthora thermophila & Fungi & Soil & $\begin{array}{l}\text { Polycyclic aromatic } \\
\text { hydrocarbons }\end{array}$ & Bulter et al. (2003) \\
\hline Acenetobacter sp. (OK1) & $\operatorname{Gram}(-\mathrm{ve})$ & $\begin{array}{l}\text { Water and } \\
\text { soil }\end{array}$ & Hydrocarbons (Petroleum) & Koren et al. (2003) \\
\hline Dechloromonas sp. (RCB) & Gram $(-v e)$ & $\begin{array}{l}\text { Water and } \\
\text { soil }\end{array}$ & Benzene, Toluene, Xylene & Chakraborty et al. (2005) \\
\hline Rhodococcus spp. & Gram $(+v e)$ & Soil & Naphthalene & Alquati et al. (2005) \\
\hline Phanerochaete chrysosporium & Fungi & Soil & Polyethylene, polypropylene & Zhou et al. (2007) \\
\hline Pleurotus sajorcaju (MTCC 141) & Fungi & Waste water & Decoloration of effluent & Yadav and Yadav (2008) \\
\hline Sinorhizobium meliloti (P221) & Gram $(-v e)$ & Soil & $\begin{array}{l}\text { Polycyclic aromatic } \\
\text { hydrocarbons }\end{array}$ & Golubev et al. (2009) \\
\hline Stenotrophomonas maltophilia (WZ2) & $\operatorname{Gram}(-\mathrm{ve})$ & Soil & Quinclorac (Herbicide) & Lü et al. (2009) \\
\hline Pseudomonas fluorescens & Gram $(-v e)$ & Waste water & Direct orange 102 dye & $\begin{array}{l}\text { Pandey and Upadhyay } \\
\text { (2010) }\end{array}$ \\
\hline Mycobacterium gilvum & Gram $(+v e)$ & Sediments & Pyrene, benzo(a)pyrene & Toyama et al. (2011) \\
\hline Saccharomyces cerevisiae & $\operatorname{Gram}(-\mathrm{ve})$ & Soil & $\begin{array}{l}\text { Chrysene, Benzo(a)pyrene, } \\
\text { Methyl red (azo dye) }\end{array}$ & $\begin{array}{l}\text { Hesham et al. (2012),Jadhav } \\
\text { et al. (2007) }\end{array}$ \\
\hline
\end{tabular}

The strains mentioned in front of corresponding microbes have been adopted from the duly acknowledged literatures

processes utilizing other readily available sources of organic carbon and energy present in the vicinity. To find the optimum conditions for growth, microbes utilize the change of chemical gradients in the vicinity. Bacterial chemotaxis is one of the best examples whereby the bacterial cells move with the change of chemical gradients (Pandey and Jain 2002), e.g., Pseudomonas putida G7 is attracted by naphthalene (Grimm and Harwood 1997). Technological advancements in microbial bioremediation include the conversion of slow biodegradation process into a rapid by means of several modern methods including microbial fuel cells (MFCs) (Rabaey and
Verstraete 2005; Moris and Jin 2012), bioreactors (Robles-González et al. 2008), biofilms (Singh et al. 2006) and the use of microbial consortia for the degradation of recalcitrant organic compounds (Torres-Bojorges and Buitro 2012).

Fungi have, however, several advantages over bacterial degrading processes as the former can grow at higher concentrations of toxic organics (Fragoeiro 2005), e.g., Phanerochaete chrysosporium (a white rot fungi) metabolize lignocellulosic compounds by the activity of degrading enzymes such as laccase (LAC), lignin peroxidase (Lip) and manganese peroxidase (Schmidt et al. 
Table 3 Some typical examples of plasmids encoded with the genes capable of catabolic degradations of organic compounds

\begin{tabular}{|c|c|c|c|}
\hline Plasmid & Isolated from microbes & Organic substrate & References \\
\hline pMFB1 & Pseudomonas pseudoalcaligens KF707 & Biphenyls, toluene, benzene & Furukawa and Miyazaki (1986) \\
\hline bphA & $\begin{array}{l}\text { Burkholderia sp. LB400, } \\
\text { Rhodococcus globerulus P6 }\end{array}$ & PCBs, biphenyls, toluene, benzene & Barriault et al. (2002) \\
\hline IsoILRI & Burkholderia sp. V106 A (Tom green) & Cis-1,1, dichloroethylene & Rui et al. (2004a) \\
\hline IsoLR1 & Rhodococcus sp. AD45 & Epoxypropane, cis-DCE & Rui et al. (2004b) \\
\hline$p N L 1$ & Sphingomonas aromaticivorans F199 & Naphthalene, biphenyls, m-xylene, $p$-cresol & Romine et al. (1999) \\
\hline$p A D P-1$ & Pseudomonas sp. ADP & Atrazine & Martínez et al. (2001) \\
\hline$p W W O$ & Pseudomonas putida $\mathrm{PaW} 1$ & Toluene, Xylene & Greated et al. (2002) \\
\hline$p C A R-1$ & Pseudomonas resinovorans CA10 & Carbazole & Maeda et al. (2003) \\
\hline$p C A R-3$ & Sphingomonas sp. KA1 & Carbazole & Shintani et al. (2007) \\
\hline$N A H-7$ & Pseudomonas putida G7 & PAHs, e.g., naphthalene & Yen and Serdar (1988) \\
\hline pDTG1 & Pseudomonas putida NCIB9816 & PAHs, e.g., naphthalene & Yen and Serdar (1988) \\
\hline pND6-1 & Pseudomonas sp. ND6 & Naphthalene & Li et al. (2004) \\
\hline$p P h C N-1$ & Pseudomonas putida $\mathrm{PhCN}$ & Phenol & El-Deeb (2009) \\
\hline pENH91 & Alcaligenes eutropha $\mathrm{NH}-9$ & $3 \mathrm{CBA}$ & Ogawan and Miyashita (1999) \\
\hline$R P 4:: T n 4371$ & Enterobacter agglomerans DK3 & Biphenyl & De Rore et al. (1994) \\
\hline pTOM 8 & Alcaligens xylosoxidans 31A & Nickel resistance & Schmidt and Schlegel (1994) \\
\hline$N i k D$ & Helicobacter pylori & Nickel resistance & Hendricks and Mobley (1997) \\
\hline
\end{tabular}

Fig. 2 Organic compounds degradation strategy followed by microbes

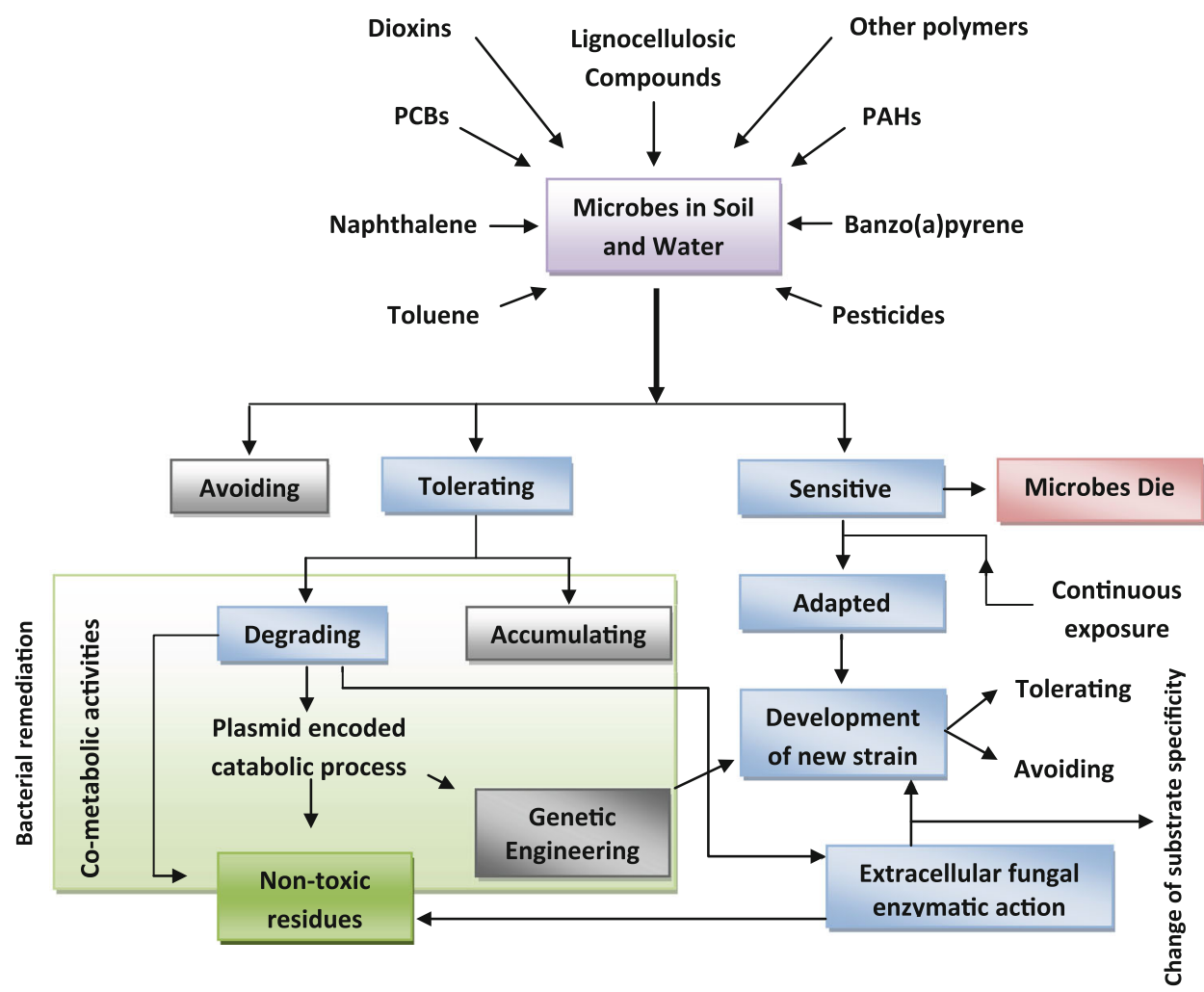


2005); similarly, catechol 2,3-dioxygenase (C-23O) produced by yeast fungi cleaves the benzene ring (Hesham et al. 2012). Table 2 presents few more examples of fungal degradation of OCs. The details of fungal role in bioremediation have been extensively reviewed by Gadd (2001). The study of factors influencing bioremediation by white rot fungi has been broadly described by Magan et al. (2010).

\section{Role of Gram-positive and Gram-negative bacteria in bioremediation}

It is interesting to understand the behavior of Grampositive and Gram-negative bacteria during their interaction with toxic organic and inorganic pollutants in environment. Gram-positive bacteria are metabolically diverse and grow on the sites contaminated with aromatic hydrocarbons and toxic metals (Narancic et al. 2012). Tables 1 and 2 show certain examples of Grampositive bacteria, e.g., Staphylococcus sp. and Rhodococcus sp., remediating environmental pollution. In addition to this, member of Rhodococcus, Bacillus, Arthrobacter, Gordonia, Streptomyces and Nocardia genus can degrade a variety of OCs, such as biphenyls, benzene (Narancic et al. 2012) and naphthalene (Alquati et al. 2005). Studies show that few other Grampositive bacteria such as Corynebacterium and Mycobacterium sp. withstand the anaerobic and extreme toxic conditions such as oil sludge (Lăzăroaie 2010). Typical examples of toxic metal tolerance in Grampositive bacteria include Bacillus megaterium MB1 resistant to mercury because of TnMERI1-resistant transposon (Huang et al. 1999). A comparative study of zinc toxicity on particular strains of Gram-positive and Gram-negative bacteria, viz., Bacillus sp., Arthrobacter sp. and Salmonella sp., by Nweke et al. (2007) showed that Gram-positive bacterial species are sensitive as compared with the Gram-negative species for the toxicity of zinc. In general, Gram-negative bacteria have better tolerance against metallic pollution (Minz et al. 1996; Nweke et al. 2007). Binding affinity with the metallic cations hardly differs between Gram-positive and Gram-negative bacteria, however; findings of Churchill et al. (1995) showed the different specificity in sorption of metal cations by Gram-positive bacteria (Micrococcus luteus) and Gram-negative bacteria (Escherichia coli), whereby $\mathrm{Co}^{2+}$ was observed to be sorbed more than $\mathrm{Ni}^{2+}$ by both $M$. luteus and E. coli in a binary mixture of cations. Lăzăroaie (2010) also reported Gram-negative bacteria to be more tolerant to toxic mixture of saturated hydrocarbons, monoaromatic hydrocarbons and polyaromatic hydrocarbons as compared with the Gram-positive bacterial cells. As evident from Tables 1 and 2, Gram-negative bacteria have wider range of toxicity tolerance of OCs and metal pollutants, however; few studies (Zahir et al. 2006; Segura et al. 2008) support that Gram-positive bacteria are even more tolerant for certain pollutants, such as hydrocarbons and PAHs, Although mechanistically Gram-negative bacteria are more tolerant because of the presence of an outer membrane made of lipopolysaccharide and proteins imparting it impermeability for toxic compounds, e.g., hydrocarbons that may be associated with the protection of microbes from being exposed to toxic elemental pollutants and OCs.

\section{Factors affecting microbial remediation}

Various biotic and abiotic factors affect the behavior and the growth of microbial cells, thereby affecting various biological processes occurring in a microbial community. Bioremediation process is subjected to the multiphasic heterogeneous surroundings (Boopathy 2000) influencing the rate of the reactions. Lack of information regarding the factors influencing the process often reduces the efficacy of process when implemented (Lovely 2003). Microbes have inherent ability of first rate to get adapted to the changing environment though they have certain limitations. In-depth understanding of microbial ecology is required for the improvement in the microbiological action and to predict the successful bioremediation process (Watanabe 2001). Figure 3 shows the environmental challenges that microbes face in their life. Three types of factors affecting the microbial processes have been shown in Fig. 3, viz., (1) physicochemical characteristics of environment or the abiotic factors, (2) biological factors or biotic factors and (3) climatic conditions whereby physicochemical and climatic conditions are among the major factors affecting the metabolic rates in microbes.

Physicochemical factors affecting bioremediation

Physicochemical factors include a set of parameters such as redox potential (Eh), $\mathrm{pH}$, ionic strength, solubility, presence or absence of electron acceptors and donors, temperature and age of organometalic ions. Biosorption, a primary step in toxic metal removal by microbes, is a $\mathrm{pH}$-dependent phenomenon whereby $\mathrm{pH}$ value influences the isoelectric point in a solution, affecting the net negative charge on the microbial cell surface. Additionally, this change brings changes in ionic state of ligands, e.g., a carboxyl residue, phosphoryl residues, $\mathrm{S}-\mathrm{H}$ groups and amino acid groups 


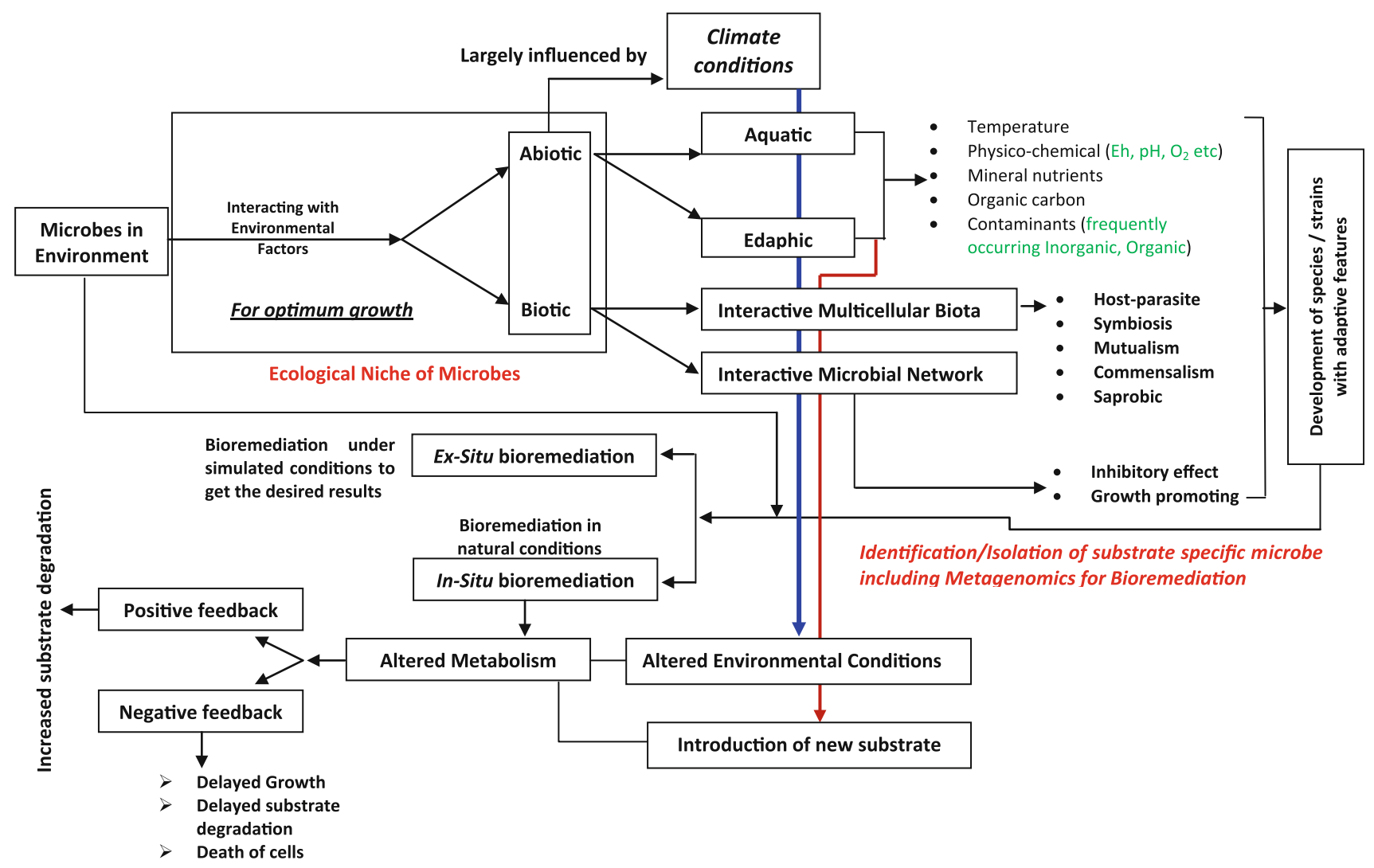

Fig. 3 Simple layout showing factors influencing the microbial ecology, thereby influencing microbial bioremediation processes

(Sag et al. 1995). Bioremediation techniques involve reduction of metal ions to insoluble form by the microorganisms from higher to lower oxidation sate ( $\mathrm{pH}$ dependent) as soluble metal ions can only undergo enzymatic reduction. Higher oxidation states of metals are generally soluble (Garbisu and Alkorta 2003). Solubility plays an important role in degradation of OCs as hydrophobic or sparingly soluble compounds persist in the environment for long lime and are biounavailable (Pieper and Reineke 2000). pH values affect the solubility of metal ions, which increases with the decrease in $\mathrm{pH}$ of medium, thereby affecting adsorption by microbial cells (Blázquez et al. 2008). In addition, lower $\mathrm{pH}$ values are required for metal ions to get attached on the microbial cell surface (Rajendran et al. 2002; Han and Gu 2010), whereas alkaline medium favors precipitation of metal ions. Organic acid-producing microorganisms Pseudomonas sp. and Burkholderia cepacia produce gluconic acid and Rhizobium sp. and Bacillus firmus produce ketogluconic acid (Robles-Gonzalez et al. 2008), which lower the pH of the system, which increases the solubility of metal ions. Organometalic compounds increase mobilization of metal ions (Puzon et al. 2005). Bioremediation is strongly inhibited by toxic metal ions, such as $\mathrm{Zn}^{2+}$, which acts as a respiratory inhibitor in microbes (Beard et al. 1995). The presence of electron acceptors, e.g., oxygen in aerobic microbes and $\mathrm{NO}_{3}{ }^{1-}, \mathrm{SO}_{4}{ }^{2-}$ and $\mathrm{Fe}(\mathrm{III})$ oxides in case of anaerobic microbes, also affects the biodegradation processes (Lovely 2003).

Biological factors affecting bioremediation processes

Biological factors are not as such very obvious, however; the importance of these factors is often realized while implementing bioremediation technique. There are several inherent characters of microbes that affect the substrate degradation, e.g., plasmid-encoded genes provide specificity for substrates and encode the specific enzymes (proteins), but it has been observed in nature that microbes, especially bacterial cells, have diversified specificity for different substrates (Mars et al. 1997). Bacterial chemotaxis is an advantageous behavior of bacteria for the degradation of recalcitrant organic compounds (Pandey and Jain 2002). As already mentioned earlier in this review, single microbial cell cannot achieve complete degradation of chemicals. Microbial communities required for bioremediation most often depend on complex multispecies 
interactive networks as shown in Fig. 3. Organohalide respiratory bacteria thrive only in consortia, and their isolation and culture is very difficult. Maphosa et al. (2010) defined it as a function of metagenomics or community genomics whereby the metagenomics sequencing helps providing data of member species of consortia that support substrate degradation. Moreover, the optimum growth conditions of microbes are unpredictable (Ingham et al. 2007). Microorganisms are vital for the efficient functioning of ecosystems on earth, and factors affecting metabolism, composition and abundance of microbes and microbial communities may disturb the ecosystems (Nweke et al. 2007). Allelopathic response of terrestrial plants on the microbial community (Chakraborty et al. 2012) may negatively influence the degradation potential of soil microbes. Solubility of OCs and the absence of oxygen cause reduction in aerobic microbial activity. Certain microbes, however, utilize other sources of organic carbon, electron acceptor and energy as cometabolic substrate and degrade the recalcitrants, e.g., Mycobacterium gilvum reportedly degrade pyrene aerobically in the rhizospheric zone of Phragmites australis simultaneously with the degradation of benzo(a)pyrene (Toyama et al. 2011). Initiation of microbial degradation of xenobiotics depends on the toxic pressure exerted by the contaminants on the microbes that induce enzymatic modifications (Pandey and Jain 2002).

\section{Climate change and bioremediation processes}

Global climate change is characterized with the factors such as elevated $\mathrm{CO}_{2}$ and atmospheric temperature. Soil microbial community plays an important role in cycling of carbon (C) as microbes exhibit increased ability to decompose soil organic matter at elevated $\mathrm{CO}_{2}$ ( Nie et al. 2013) and nutrients in ecosystems which are largely influenced by biotic and abiotic factors (Fig. 3). There is no direct evidence of any likely impacts of climate change on the bioremediation process, however; researches on soil microbes and climate change (Sowerby et al. 2005; Castro et al. 2010; Nie et al. 2013) suggest changes in the physicochemical properties of the microbial niche, which may alter microbial metabolic processes and thereby the bioremediation. Microbial extracellular enzyme production is linked to microbial activity as well as soil physicochemical properties (Sowerby et al. 2005), which are influenced by climatic conditions. One of the breakthrough findings belongs to Frey et al. (2013), whereby increased utilization efficiency of recalcitrant substrate in soils by the microbes at higher temperature as a positive feedback to climate has been reported although the feedbacks from ecosystems to the climate have reportedly been regulated by microbial communities (Bardgett et al. 2008). Elevated ambient $\mathrm{CO}_{2}$ level has been found associated with the increase in bacterial abundance (Castro et al. 2010) and decreased fungal abundance (Frey et al. 2008). Decrease in fungal biomass at warm and dry conditions decreases the fungal/bacterial biomass ratio in soil (Sowerby et al. 2005), indicating decreased magnitude of carbon cycling in an ecosystem which further disturbs the natural degradation process by naturally occurring microbes capable of degrading the hazardous chemicals cometabolically facilitated by the naturally available carbon. It has been predicted that if temperature of soil increases due to the global climate change, microbial enzymatic activity will rise substantially (Baldrian et al. 2013).

\section{Future studies in bioremediation}

Issues related to the metagenomics (community structure), identification of microbes and their implementation on the bioremediation under altered environmental conditions may be the main thrust of future studies. Since the urbanization is a global phenomenon, the urban waste treatment with naturally occurring and genetically modified microbes is not a cost-effective process as it needs a proper facility requiring extensive economic support. Although commercial use of waste treatment is now a realization, the incurred input of money is far greater than the output. Scientists are continuously making efforts to get the economical gains of microbial remediation of waste generated. These include the environmentally safe energy production from the waste through microbial activity, production of biofertilizers and recycling of material. Several other issues including mechanistic approach of degradation/removal, microbial response to changing environment, recalcitrant metabolites, proteomics and the chemistry of new xenobiotic compounds are some of the endless studies yet to investigate comprehensively. Adaptability features of microbes make it more difficult for the researchers to ascertain the specific pollution remediation technique; therefore, more precise techniques are required to identify microbes and the substrate specificity as well. Microbial resistance development for various organic chemicals through transformation of genetic information between microbes and the rate of this exchange may need a scientific surveillance study to ensure the complete safety of the living world from the extensively resistant strains. 


\section{Conclusion}

Organic and inorganic contaminants deteriorated the environment on the earth because of their deliberate and accidental leakage or production and generation in the form of waste. Microbial bioremediation of these contaminations has attracted the researchers all over the world as microbes naturally offer plenty of opportunities for the cleaning-up of the polluted sites. Advancements in this field of science have widely been made. With the genetic engineering know-how, microbes are being designed precisely termed as "synthetic biology" by Endy (2005) whereby particular genes responsible for the degradation of contaminants are transferred to the microorganisms of common occurrence provided the correct identification and culturing of isolates. Thanks to metagenomics that provide information of the microbial community structure acting upon environmental pollutants. There are several biomolecular techniques available to identify microbes in consortia and to ascertain the degradation of xenobiotic compounds. We are now able to understand the degradation processes of most commonly used xenobiotics including polyaromatic hydrocarbons (PAHs), e.g., naphthalene (Alquati et al. 2005), benzene (Xiong et al. 2012), chrysene and benzo(a)pyrene (Hesham et al. 2012). For a successful bioremediation, knowledge of factors influencing the biological as well as physicochemical processes is must. Tools of molecular biology are being used to identify the target-specific microorganisms and their mechanisms of chemical degradation and still an open opportunity to understand the natural bioremediation process. Future prospects of researches in microbial bioremediation have still a lot of opportunities for the imminent scientists. Since climate is changing along with its associated impacts that can alter the microbial communities, it is predicted that climate change will alter the earth's ecosystem as a whole, however; reports indicate the increased microbial activity at elevated $\mathrm{CO}_{2}$ and temperature. The climate change and microbial processes in nature will certainly be the interesting field of future research.

Acknowledgments The authors wish to appreciate all who supported this work.

\section{References}

Abou-Shanab RA, Angle JS, Delorme TA, Chaney RL, van Berkum P, Moawad H, Ghanem K, Ghozlan HA (2003) Rhizobacterial effects on nickel extraction from soil and uptake by Alyssum murale. New Phytol 158:219-224
Abou-Shanab RAI, Angle JS, Chaney RL (2006) Bacterial inoculants affecting nickel uptake by Alyssum murale from low, moderate and high Ni soils. Soil Biol Biochem 38:2882-2889

Alquati C, Papacchini M, Riccardi C, Spieaglia S, Bestetti G (2005) Diversity of naphthalene degrading bacteria from a petroleum contaminated soil. Ann Microbiol 55(4):237-242

Ang EL, Zhao H, Obbard JP (2005) Recent advances in the bioremediation of persistent organic pollutants via biomolecular engineering. Enzyme Microb Technol 37:487-496

Arriagada CA, Herrera MA, Borie F, Ocampo JA (2007) Contribution of arbuscular mycorrhizal and saprobe fungi to the aluminum resistance of Eucalyptus globulus. Water Air Soil Poll 182:383-394

Badri DV, Weir TL, Van-der-Lelie D, Vivance JM (2009) Rhizosphere chemical dialogues: plant-microbe interactions. Curr Opin Biotechnol 20:642-650

Bais HP, Weir TL, Perry LG, Gilroy S, Vivanco JM (2006) The role of root exudates in rhizosphere interactions with plants and other organisms. Annu Rev Plant Biol 57:233-266

Baldrian P, Šnajdr J, Merhautova V, Dobiášová P, Cajthaml T, Valášková V (2013) Responses of the extracellular enzyme activities in hardwood forest to soil temperature and seasonality and the potential effects of climate change. Soil Biol Biochem 56:60-68

Bardgett RD, Freeman C, Ostle NJ (2008) Microbial contributions to climate change through carbon cycle feed backs. ISME J 2:805-814

Barriault D, Plante MM, Sylvestre M (2002) Family shuffling of a targeted bphA region to engineer biphenyl dioxygenase. J Bacteriol 184:3794-3800

Bayramoğlu G, Çelik G, Arica MY (2006) Studies on accumulation of uranium by fungus Lentinus sajor-caju. J Hazard Mater 136(2):345-353

Beard SJ, Hughes MN, Poole RK (1995) Inhibition of the cytochrome bd-terminated NADH oxidase system in Escherichia coli K-12 by divalent metal cations. FEMS Microbiol Lett 131:205-210

Blázquez G, Hernáinz F, Calero M, Martin-Lara MA, Tenorio G (2008) The effect of $\mathrm{pH}$ on the biosorption of $\mathrm{Cr}(\mathrm{III})$ and $\mathrm{Cr}(\mathrm{VI})$ with olive stone. Chem Eng J 148:473-479

Boopathy R (2000) Factors limiting bioremediation technologies. Biores Technol 74:63-67

Bosch R, Garcia-Valdez E, Moore ER (2000) Complete nucleotide sequence and evolutionary significance of chromosomally encoded naphthalene degradation lower pathway from Pseudomonas stutzeri AN10. Gene 245:65-74

Bulter T, Alcade M, Steber V, Meinhold P, Schlachtbauer C, Arnold FH (2003) Functional expression of fungal laccase in Saccharomyces cerevisiae by directed evolution. Appl Environ Microb 69:987-995

Cardenas E, Wu W, Leigh MB, Carley J, Carroll S, Gentry T, Luo J, Watson D, Gu B, Ginder-Vogel M, Kitanidis PK, Jardin PM, Zhou J, Criddle CS, Marsh TL, Tiedje JM (2008) Microbial communities in contaminated sediments, associated with bioremediation of uranium to submicromolar levels. Appl Environ Microb 74(12):3718-3729

Castro HF, Classen AT, Austin EE, Norby RJ, Schadt CW (2010) Soil microbial community responses to multiple experimental climate change drivers. Appl Environ Microb 76(4):999-1007

Chakraborty R, O'Connor SM, Chan E, Coates JD (2005) Anaerobic degradation of benzene, toluene, ethylbenzene, and xylene compounds by Dechloromonas strain RCB. Appl Environ Microb 71:8649-8655

Chakraborty S, Pangga IB, Roper AM (2012) Climate change and multitrophic interactions in soil: the primacy of plants and functional domains. Glob Change Biol 18:2111-2125 
Chaloupkova R, Sykorova J, Prokop Z, Jesenska A, Monincova M, Pavlova M, Tsuda M, Nagata Y, Damborsky J (2003) Modification of activity and specificity of haloalkane dehalogenase from Sphingomonas paucimobilis UT26 by engineering of its entrance tunnel. J Biol Chem 278:52622-52628

Chiang SY, Mora R, Diquiseppi WH, Davis G, Sublette K, Gedalanga P, Mahendra S (2012) Characterizing the intrinsic bioremediation potential of 1, 4-dioxane and trichloroethene using innovative environmental diagnostic tools. $\mathrm{J}$ Environ Monit 14(9):2317-2326

Chojnacka K (2010) Biosorption and bioaccumulation - the prospects for practical applications. Environ Int 36:299-307

Churchill SA, Waiters JV, Churchill PF (1995) Sorption of heavy metals by prepared bacterial cell surfaces. J Environ Eng 121(10):706-711

Contzen M, Stolz A (2000) Characterization of the genes for two protocatechuate 3,4-dioxygenases from the 4-sulfocatecholdegrading bacterium Agrobacterium radiobacter Strain S2. J Bacteriol 182(21):6123-6129

De Rore H, Demolder K, De Wilde K, Top E, Houwen F, Verstraete W (1994) Transfer of the catabolic plasmid RP4:Tn4371 to indigenous soil bacteria and its effect on respiration and biphenyl breakdown. FEMS Microbiol Ecol 15:71-81

El-Deeb B (2009) Natural combinations of genetic systems for degradation of phenol and resistance to heavy metals in phenol and cyanide assimilating bacteria. Malay $\mathrm{J}$ Microbiol $5(2): 94-103$

Endy D (2005) Foundation for engineering biology. Nature 438:449-453

Fennell DE, Du S, Liu H, Liu F, Häggblom MM (2011) Dehalogenation of polychlorinated dibenzo-p-dioxins and dibenzofurans, polychlorinated biphenyls and brominated flame retardants and potential as a bioremediation strategy. In: Moo-Young M, Butler M, Webb C, Moreira A, Grodzinski B, Cui ZF, Agathos S (eds) Comprehensive biotechnology, 2nd edn. Pergamon Press, Oxford, pp 136-149

Finnegan I, Toerien S, Abbot L, Smit F, Raubenheimer HG (1991) Identification and characterization of an Acinetobacter sp. capable of assimilation of a range of cyano-metal complexes, free cyanide ions and simple organic nitriles. Appl Microbiol Biotechnol 36:142-144

Fragoeiro S (2005) Use of fungi in bioremediation of pesticides [dissertation]. Cranfield University, Bedford

Fragoeiro S, Magan N (2008) Impact of Trametes versicolor and Phanerochaete crysosporium on differential breakdown of pesticide mixtures in soil microcosm at two water potential and associated respiration and enzyme activity. Int Biodeterior Biodegradation 62:376-383

Frey SD, Drijber R, Smith H, Melillo J (2008) Microbial biomass functional capacity and community structure after 12 years of soil warming. Soil Biol Biochem 40:2904-2907

Frey SD, Lee J, Melillo JM, Six J (2013) The temperature response of soil microbial efficiency and its feedback to climate. Nat Clim Chang 3:395-398

Furukawa K, Miyazaki T (1986) Cloning of a gene cluster encoding biphenyl and chlorobiphenyl degradation in Pseudomonas pseudoalcaligenes. J Bacteriol 166(2):392-398

Gadd GM (2001) Fungi in bioremediation. Cambridge University Press, Cambridge

Garbisu C, Alkorta I (2003) Basic concepts on heavy metal soil bioremediation. Euro J Mineral Process Environ Prot 3(1):58-66

Glick BR (2010) Using soil bacteria to facilitate phytoremediation. Biotechnol Adv 28:367-374

Golubev SN, Schelud'ko A, Muratova AY, Makarov OE, Turkovskaya OV (2009) Assessing the potential of rhizobacteria to survive under phenanthrene pollution. Water Air Soil Poll 198(1-4):5-16

Goyal N, Jain SC, Banerjee UC (2003) Comparative studies on the microbial adsorption of heavy metals. Adv Environ Res 7:311-319

Greated A, Lambertsen L, Williams PA, Thomas CM (2002) Complete sequence of the IncP-9 TOL plasmid $P W W O$ from Pseudomonas putida. Environ Microbiol 4:856-871

Grimm AC, Harwood CS (1997) Chemotaxis of Pseudomonas sp. to the polycyclic aromatic hydrocarbon, naphthalene. Appl Environ Microbiol 63:4111-4115

Grosser RJ, Friedrich M, Ward DM, Inskeep WP (2000) Effect of model sorptive phases on phenanthrene biodegradation: different enrichment conditions influence bioavailability and selection of phenanthrene-degrading isolates. Appl Environ Microbiol 66:2695-2702

Gupta R, Ahuja P, Khan S, Saxena RK, Mohapatra H (2000) Microbial biosorbents: meeting challenges of heavy metal pollution in aqueous solution. Curr Sci India 78:967-973

Han X, Gu J (2010) Sorption and transformation of toxic metals by microorganisms. In: Mitchell R, Gu J (eds) Environmental microbiology. Wiley Blackwell Pub, Hoboken

Harrison MJ (2005) Signaling in arbuscular mycorrhizal symbiosis. Annu Rev Microbiol 59:19-42

Hedlund BP, Staley JT (2001) Vibrio cyclotrophicus sp. nov., a polycyclic aromatic hydrocarbon (PAH) - degrading marine bacteria. Int J Syst Evol Microbiol 51:61-66

Hendricks JK, Mobley HL (1997) Helicobacter pylori ABC transporter: effect of allelic exchange mutagenesis on urease activity. J Bacteriol 179(18):5892-5902

Hesham Ael-L, Khan S, Tao Y, Li D, Zhang Y, Yang M (2012) Biodegradation of high molecular weight PAHs using isolated yeast mixtures: application of metagenomic methods for community structure analyses. Environ Sci Pollut Res Int 19(8):3568-3578

Hiraishi A (2008) Biodiversity of dehalorespiring bacteria with special emphasis on polychlorinated biphenyl/dioxin dechlorinators. Microbes Environ 23:1-12

Hong SH, Jeong HD, Jung B, Lee EY (2012) Analysis and quantification of ammonia-oxidizing bacteria community with amo A gene in sewage treatment plants. J Microbiol Biotechnol 22(9): 1193-1201

Huang CC, Narita M, Yamagata T, Itoh Y, Endo G (1999) Structure analysis of a class II transposon encoding the mercury resistance of the Gram-positive bacterium Bacillus megaterium MB1, a strain isolated from Minamata Bay, Japan. Gene 234:361-369

Ingham CJ, Sprenkels A, Bomer J, Molenaar D, Van Den Berg A, van Hylckama Vlieg JE, de Vos WM (2007) The micro Petri dish, a million-well growth chip for the culture and high- throughput screening of microorganisms. Proc Natl Acad Sci USA 104:18217-18222

Jadhav JP, Parshetti GK, Kalme SD, Govindwar SP (2007) Decolourization of azo dye methyl red by Saccharomyces cerevisiae MTCC 463. Chemosphere 68:394-400

Joerger TK, Joerger R, Olsson E, Granqvist CG (2001) Bacteria as workers in the living factory: metal accumulating-bacteria and their potential for material science. Trends Biotechnol 19:15-20

Kabata-Pendius A, Mukherjee AB (2007) Trace elements from soil to human. Springer, New York

Kaewsarn P, Yu Q (2001) Cadmium (II) removal from aqueous solutions by pre-treated biomass of marine algae (Padina sp). Environ Pollut 112:209-213

Katsoyiannis IA, Zouboulis AI (2004) Application of biological processes for the removal of arsenic from ground waters. Wat Res 38:17-26 
Kim SU, Cheong YH, Seo DC, Hur JS, Heo JS, Cho JS (2007) Characterization of heavy metal tolerance and biosorption capacity of bacterium strain CPB4 (Bacillus spp.). Water Sci Technol 55(1-2):105-111

Koren O, Knezevic V, Ron EZ, Rosenberg E (2003) Petroleum pollution bioremediation using water-insoluble uric acid as the nitrogen source. Appl Environ Microbiol 69(10):6337-6339

Lăzăroaie MM (2010) Multiple response of gram positive and gram negative bacteria to mixture of hydrocarbons. Braz J Microbiol 41:649-667

Leahy JG, Tracy KD, Eley MH (2003) Degradation of mixtures of aromatic and aliphatic hydrocarbons by aromatic hydrocarbondegrading bacteria. FEMS Microbiol Ecol 43(2):271-276

Li W, Shi J, Wang X, Han Y, Tong W, Ma L, Liu B, Cai B (2004) Complete nucleotide sequence and organization of the naphthalene catabolic plasmid pND6-I from Pseudomonas sp. strain ND6. Gene 336:231-240

Lovely DR (2003) Cleaning up with genomics applying molecular biology to bioremediation. Nat Rev Microbiol 1:35-44

Lovely DR, Coates JD (1997) Bioremediation of metal contamination. Curr Opin Biotech 8:285-289

Lovely DR, Lloyd JR (2000) Microbes with a metal for bioremediation. Nat Biotechnol 18:600-601

Lü Z, Sang L, Li Z, Min H (2009) Catalase and superoxide dismutase activities in a Stenotrophomonas maltophilia WZ2 resistant to herbicide pollution. Ecotoxicol Environ Saf 72:136-143

Luef B, Fakra SC, Csencsits R, Wrighton KC, Williams KH, Wilkins MJ, Downing KH, Long PE, Comolli LR, Banfield JF (2013) Iron-reducing bacteria accumulate ferric oxyhydroxide nanoparticle aggregates that may support planktonic growth. ISME J $7: 338-350$

Mabbett AN, Lloyd JR, Macaskie LE (2002) Effect of complexing agents on reduction of $\mathrm{Cr}(\mathrm{VI})$ by Desulfovibrio vulgaris ATCC 29579. Biotechnol Bioeng 79:389-397

Maeda K, Nojiri H, Shintani H, Yoshida T, Habe H, Omori T (2003) Complete nucleotide sequence of carbazole/dioxin degrading plasmid pCARlin Pseudomonas resinovorans strain CA10 indicates its mosaicity and the presence of large catabolic transposon Tn4676. J Mol Biol 326:21-23

Magan N, Fragoeiro S, Bastos C (2010) Environmental factors and bioremediation of xenobiotics using white rot fungi. Mycobiol 38(4):238-248

Malik A (2004) Metal bioremediation through growing cells. Environ Int 30:261-278

Maphosa F, Smidt H, De Vos WM, Roling WFM (2010) Microbial community and metabolite dynamics of an anoxic dechlorinating bioreactor. Environ Sci Technol 44:4884-4890

Maphosa F, Lieten SH, Dinkla I, Stams AJ, Smidt H, Fennell DE (2012) Ecogenomics of microbial communities in bioremediation of chlorinated contaminated sites. Front Microbiol $3: 1-14$

Margesin R, Schinner F (2001) Biodegradation and bioremediation of hydrocarbons in extreme environments. Appl Microbiol Biotechnol 56:650-663

Margesin R, Zimmerbauer A, Schinner F (2000) Monitoring of bioremediation by soil biological activities. Chemosphere 40:339-346

Mars AE, Kasberg T, Kaschabek SR, van-Agteren MH, Janssen DB, Reineke W (1997) Microbial degradation of chloroaromatics: use of the meta-cleavage pathway for mineralization of chlorobenzene. J Bacteriol 179:4530-4537

Martínez B, Tomkins J, Wackett LP, Wing R, Sadowsky MJ (2001) Complete nucleotide sequence and organization of the atrazine catabolic plasmid pADP-1 from Pseudomonas sp. strain ADP. J Bacteriol 183:5684-5697
Meehan C, Banat IM, McMullan G, Nigam P, Smyth F, Marchant R (2000) Decolorization of remazol black - B using q thermotolerant yeast Kluyveromyces marxianus IMB3. Environ Int 26(1-2):75-79

Mergeay M (1991) Towards an understanding of the genetics of bacterial metal resistance. Trends Biotechnol 9:17-24

Mikulasova M, Kosikova B, Alexy P, Kacik F, Urgelova E (2001) Effect of blending lignin biopolymer on the biodegradability of polyolefin plastics. World J Microbiol Biotechnol 17:601-607

Minz D, Rosenburg E, Ron EZ (1996) Cadmium binding bacteria: screening, and characterization of new isolates and mutants. FEMS Microbiol Lett 135:191-194

Moris JM, Jin S (2012) Enhanced biodegradation of hydrocarbon contaminated sediments using microbial fuel cells. J Hazard Mater 30(213-214):474-477

Murugesan K (2003) Bioremediation of paper and pulp mill effluents. J Exp Biol 41(11):1239-1248

Nam K, Rodriguez W, Kukor JJ (2001) Enhanced degradation of polycyclic aromatic hydrocarbons by biodegradation combined with a modified Fenton reaction. Chemosphere 45:11-20

Naraian R, Ram S, Kaistha SD, Srivastava J (2012) Occurrence of plasmid linked multiple drug resistance in bacterial isolates of tannery effluent. Cell Mol Biol 58(1):134-141

Narancic T, Djokic L, Kenny ST, O'Connor KE, Rodulovic V, Nikodinovic-Runic J, Vasilijevic B (2012) Metabolic versatility of gram positive microbial isolates from contaminated river sediments. J Hazard Mater 15(215-216):243-251

Nie M, Pendall E, Bell C, Gasch CK, Raut S, Tamang S, Wallenstein MD (2013) Positive climate feedbacks of soil microbial communities in a semi-arid grassland. Ecol Lett 16(2):234-241

Nweke CO, Alisi CS, Okolo JC, Nwanyanwu CE (2007) Toxicity of zinc heterotrophic bacteria from a tropical river sediment. Appl Ecol Environ Res 5(1):123-132

Ogawan N, Miyashita K (1999) The chloro catechol-catabolic transposon Tn5707 of Alcaligenes eutrophus NH9 carrying a gene cluster highly homologous to that in the 1, 2, 4-trichlorobenzene-degrading bacterium Pseudomonas sp. strain P51, confers the ability to grow on 3-chlorobenzoate. Appl Environ Microbiol 65:724-731

Pandey G, Jain RK (2002) Bacterial chemotaxis towards environmental pollutants: role in bioremediation. Appl Environ Microbiol 68(12):5789-5795

Pandey BV, Upadhyay RS (2010) Pseudomonas fluorescens can be used for bioremediation of textile effluent direct orange- 102 . Tropical Ecol 51(2S):397-403

Parales RE, Ditty JL, Harwood CS (2000) Toluene degrading bacteria are chemotactic towards the environmental pollutants benzene, toluene and trichloroethylene. Appl Environ Microbiol 66:4098-4104

Paul D, Pandey G, Pandey J, Jain RK (2005) Accessing microbial diversity for bioremediation and environmental restoration. Trends Biotechnol 23(3):135-142

Pazirandeh M, Chrisey LA, Mauro JM, Campbell JR, Gaber BP (1995) Expression of the Neurospora crassa metallothionein gene in Escherichia coli and its effects on heavy-metal uptake. Appl Microbiol Biotechnol 43:1112-1117

Pieper DH, Reineke W (2000) Engineering bacteria for bioremediation. Curr Opin Biotech 11:262-270

Puzon GJ, Roberts AG, Kramer DM, Xun L (2005) Formation of soluble organo-chromium (III) complexes after chromate reduction in the presence of cellular organics. Environ Sci Technol 39:2811-2817

Rabaey K, Verstraete W (2005) Microbial fuel cells: novel biotechnology for energy generation. Trends Biotechnol 23(6):291-298

Rajendran P, Muthukrishnan J, Gunasekaran P (2002) Current perspective in nickel bioremediation strategies. Indian J Microbiol 42:1-9 
Rajkumar M, Ae N, Prasad MNV, Freitas H (2010) Potential of siderophore-producing bacteria for improving heavy metal phytoextraction. Trends Biotechnol 28:142-149

Rajkumar M, Prasad MNV, Swaminathan S, Freitas H (2013) Climate change driven plant-metal-microbe interactions. Environ Int 53:74-86

Riccardi C, Papacchini M, Mansi A, Ciervo A, Petrucca A, LaRosa G, Marianelli C, Muscillo M, Marcelloni AM, Spicagilla S (2005) Characterization of bacterial population coming from a soil contaminated by polycyclic aromatic hydrocarbons (PAHs) able to degrade pyrene in slurry phase. Ann Microbiol 55(2):85-90

Robles-Gonzalez IV, Fava F, Poggi-Varaldo HM (2008) A review on slurry bioreactors for bioremediation of soils and sediments. Microb Cell Factor 7(5):1-16

Romine MF, Stillwell LC, Wong K, Thurston SJ, Sisk EC, Sensen C, Gaasterland T, Fredrickson JK, Saffer JD (1999) Complete sequence of 184 kilobase catabolic plasmid from Sphingomonas aromaticivorans F199. J Bacteriol 181(5):1585-1602

Rui L, Cao L, Chen W, Reardon KF, Wood TK (2004a) Active site engineering of the epoxide hydrolase from Agrobacterium radiobacter $\mathrm{AD} 1$ to enhance aerobic mineralization of cis-1, 2dichloroethylene in cells expressing an evolved toluene orthomonooxygenase. J Biol Chem 279:46810-46817

Rui L, Kwon YM, Reardon KF, Wood TK (2004b) Metabolic pathway engineering to enhance aerobic degradation of chlorinated ethenes and to reduce their toxicity by cloning a novel glutathione S-transferase, an evolved toluene ortho-monooxygenase, and gamma-glutamylcysteine synthetase. Environ Microbiol 6:491-500

Sag Y, Ozer D, Kustal T (1995) A comparative study of the biosorption of lead (II) ions to Zoogloea ramigera and Rhizopus arrhizus. Process Biochem 30:169-174

Samuelson P, Wernerus H, Svedberg M, Sthal S (2000) Staphylococcal surface display of metal binding polyhistidyl peptides. Appl Environ Microbiol 66:1243-1248

Sar P, D'Souza SF (2001) Biosorptive uranium uptake by a Pseudomonas, strain: characterization and equilibrium studies. J Chem Technol Biotechol 76(12):1286-1294

Schmidt T, Schlegel HG (1994) Combined nickel cobalt-cadmium resistance encoded by the ncc locus of Alcaligens xylosoxidans 31A. J Bacteriol 176(22):7045-7054

Schmidt KR, Chand S, Gostomski PA, Boyd-Wilson KS, Ford C, Walter M (2005) Fungal inoculum properties and its effect on growth and enzyme activity of Trametes versicolor in soil. Biotechnol Prog 21:377-385

Segura A, Hurtado A, Rivera B, Lăzăroaie MM (2008) Isolation of new toluene-tolerant marine strains of bacteria and characterization of their solvent-tolerance properties. J Appl Microbiol 104:1408-1416

Shintani M, Urata M, Inove K, Eto K, Habe H, Omori T, Yamane H, Nojiri H (2007) The Sphingomonas plasmid $p C A R 3$ is involved in complete mineralization of carbazole. $\mathrm{J}$ Bacteriol 189(5):2007-2020

Shukla OP, Rai UN (2006) Hexavalent chromium induced changes in growth and biochemical responses of chromate-resistant bacterial strains isolated from tannery effluent. Bull Environ Contam Toxicol 77:96-103

Shukla OP, Rai UN, Dubey S (2009) Involvement and interaction of microbial communities in the transformation and stabilization of chromium during the composting of tannery effluent treated biomass of Vallisneria spiralis L. Biores Technol 100:2198-2203

Singh R, Paul D, Jain RK (2006) Biofilms: implications in bioremediation. Trends Microbiol 14(9):389-397
Sowerby A, Emmett B, Beier C, Tietema A, Periuelas J, Estiarte M, van Meeteren MJM, Hughes S, Freeman C (2005) Microbial community changes in heath land soil communities along a geographical gradient: interaction with climate change manipulations. Soil Biol Biochem 37(10):1805-1813

Srivastava J, Chandra H, Tripathi K, Naraian R, Sahu RK (2008) Removal of chromium (VI) through biosorption by the Pseudomonas spp. isolated from tannery effluent. J Basic Microb 48:135-139

Srivastava J, Shukla D, Chand V, Naraian R, Chandra H, Nautiyal AR (2010) Mycorrhizal colonization affects the survival of Vetiveria zizanioides (L.) Nash grown in water containing As (III). Cleansoil Air. Water 38(8):771-774

Tan WS, Ting AS (2012) Efficacy and reusability of alginateimmobilized live and heat inactivated Trichoderma asperellum cells for $\mathrm{Cu}$ (II) removal from aqueous solutions. Biores Technol 123:290-295

Torres-Bojorges AX, Buitrón G (2012) Biodegradation of nonylphenols using nitrifying sludge, 4-chlorophenol adapted consortia and activated sludge in liquid and solid phases. Environ Technol 33(13-15): 1727-1737

Toyama T, Furukawa T, Maeda N, Inoue D, Sei K, Mori K, Kikuchi S, Ike M (2011) Accelerated biodegradation of pyrene and benzo(a)pyrene in the Phragmites australis rhizosphere by bacteria-root exudates interactions. Water Res 45(4):1629-1638

Tyagi M, da Fonseca MMR, de Carvalho CCCR (2011) Bioaugmentation and biostimulation strategies to improve the effectiveness of bioremediation processes. Biodegradation 22:231-241

Vasudevan P, Padmavathy V, Tewari N, Dhingra SC (2001) Biosorption of heavy metal ions. J Sci Ind Res 60:112-120

Watanabe K (2001) Microorganisms relevant to bioremediation. Curr Opin Biotech 12:237-241

Watanabe K, Watanabe K, Kodoma Y, Syutsubo K, Harayama S (2000) Molecular characterization of bacterial populations in petroleum contaminated groundwater discharged from underground crude oil storage cavities. Appl Environ Microbiol 66:4803-4809

Weber KP, Leqqe RL (2013) Comparison of the catabolic activity and catabolic profiles of rhizospheric gravel associated and interstitial microbial communities in treatment wetlands. Water Sci Technol 67(4):886-893

Wei Z, Xi B, Zhao Y, Wang S, Liu H, Jiang Y (2007) Effect of inoculating microbes in municipal solid waste composting on characteristics of humic acid. Chemosphere 68:368-374

Widada J, Nojiri H, Omori T (2002) Recent developments in molecular techniques for identification and monitoring of xenobiotic degrading bacteria and their catabolic genes in bioremediation. Appl Microbiol Biotechnol 60:45-59

Wong PK, Yuen PY (1998) Decolourization and biodegradation of N, N-dimethyl-p-phenylenediamine by Klebsiella pneumoniae RS13 and Acetobacter liquefaciens S-1. J Appl Microbiol 85:79-87

Wood TK (2008) Molecular approaches in bioremediation. Curr Opin Biotechnol 19:572-578

Wood JM, Wang HK (1985) Microbial resistance to heavy metals. In: Ingrolic KJ, Martel AE (eds) Environmental inorganic chemistry. Wiley-VCH Publishers Inc, Dear Field Beach, pp 487-512

Xiong W, Mathies C, Bradshaw K, Carlson T, Tang K, Wang Y (2012) Benzene removal by a novel modification of enhanced anaerobic biostimulation. Water Res 46(15):4721-4731

Yadav M, Yadav KS (2008) Decolorization of pulp paper mill effluent by Pleurotus sajor-caju. J Environ Sci Eng 50(2):89-92

Yassine MH, Suidan MT, Venosa AD (2013) Microbial kinetic model for the degradation of poorly soluble organic materials. Water Res 47(4):1585-1595 
Yen KM, Serdar CM (1988) Genetics of naphthalene catabolism by Pseudomonas. Crit Rev Microbiol 15:247-268

Zahir Z, Seed KD, Dennis TJ (2006) Isolation and characterization of novel organic solvent tolerant bacteria. Extremophiles 10:129-138

Zhang SY, Wang QF, Xie SG (2012) Molecular characterization of phenanthrene-degrading methanogenic communities in leachatecontaminated aquifer sediment. Int J Environ Sci 9(4):705-712
Zhou J, Jiang W, Ding J, Zhang X, Gao S (2007) Effect of tween 80 and beta-cyclodextrin on degradation of decabromodiphenyl ether (BDE-209) by white rot fungi. Chemosphere 70(2):172-177

Zhuang L, Gui L, Gillham RW (2012) Biodegradation of pentaerythritol tetranitrate (PETN) by anaerobic consortia from a contaminated site. Chemosphere 89(7):810-816 